Pegem Journal of Education\&Instruction,4(3), 2014, 01-18

Pegem Eğitim ve Öğretim Dergisi, 4(3), 2014, 01-18

www.pegegog.net

\title{
Factors Related with Students' Foreign Language Achievement
}

Sinem VATANARTIRAN ${ }^{* a}$, Gülay DALGIÇ ${ }^{a}$, Şirin KARADENIZ ${ }^{a}$

${ }^{a}$ Bahçeşehir University, Faculty of Educational Sciences, Istanbul/Turkey

\section{Article Info}

DOI: $10.14527 /$ pegegog.2014.013

Article history:

Received 24 October 2013

Revised 23 March 2014

Accepted 01 July 2014

Keywords:

Foreign language achievement, Predicting variables,

National tests.

\begin{abstract}
This study aims to identify the predicting variables of Turkish 7th grade students for their foreign language achievements. In order to project the variables that could be related with students' achievement in a foreign language test, Multi Linear Regression Analysis was employed. The results reveal that region, gender, family education level, family income level, attitude, and out-of-school activities explain students' foreign language achievement to the degree of $16 \%$ in Turkey at country level $(F=77.791, R=$ .398, $\mathrm{p}=.000$ ). All of these variables predict the foreign language achievement meaningfully in a positive direction at least at $p<.05$ significance level. The model formed of these variables create meaningful results for all geographical regions except for East and South Eastern Anatolian regions, where the results were not meaningful at $p<.05$ significance level.
\end{abstract}

\section{Introduction}

There have been numerous studies that focus on identifying factors that affect students' academic achievement (Carroll, 1963; Creemers, 1994; Edmonds, 1979; Scheerens \& Bosker, 1997). In these studies, these factors are examined at national, regional, school, classroom, and student levels (Bos \& Kuiper, 1999; Cotton, 1995; Hanushek, 1997; Levine\&Lezotte, 1990; Purkey \&Smith, 1983; Ramirez, 2006; Sammons, Hillman \& Mortimore, 1995; Scheerens, 1992, 2004; Woessmann, 2004; Yang, 2003; Zhao, 2013). There are several international assessment projects for examining student academic achievement at these levels such as TIMSS (Trends in International Mathematics and Science Study), PISA (The Programme for International Student Achievement), and PIRLS (Progress in International Reading Literacy Study). Turkey has been part of these international student assessment projects since 1999. A pilot study similar in nature to these international assessment projects was conducted in 2008 by a private educational research institution in Turkey aiming at identifying some factors predicting student academic achievement at student, classroom, school, and nation level. In this study, the data collected in the previously mentioned pilot study was used to identify some student level factors that predict 7th grade students' foreign language achievement. These factors are selected as region, gender, attitude to learning a foreign language, out-of-school activities, parental education level, and family income level. The research questions of this study are the followings:

- What is the foreign language academic achievement of 7 th grade students in relation with region and gender?

- Does student foreign language achievement show significant differences in relation with region and gender?

- Do variables such as region, gender, attitude to learning a foreign language, out-of-school activities, parental education level, and family income level predict student foreign language achievement regionally and nationwide?

*Corresponding author: sinem.vatanartiran@es.bahcesehir.edu.tr 


\section{Method}

\section{Participants}

The sample of the study is 4582 students registered at 64 branches of a test preparation center that had branches countrywide. These students are preparing for the national achievement test, called SBS (Seviye Belirleme Sınavı / National Achievement Test) that the students take at the end of elementary school. 2308 of the participants (50.4\%) were females, 2266 of them (49.5\%) were males. The distribution of these students according to the geographical regions of Turkey is as follows: Mediterranean (14.2\%), East Anatolia (2.3\%), Aegean (20.3\%), South East Anatolia (0.8\%), Central Anatolia (20.3\%), Black Sea (12.6\%), and Marmara (29.6\%). This distribution is parallel with TUIK's population census results $\left(x^{2}=35.00, p=.243\right)$.

\section{Instrument}

Two instruments were used to collect data. The first one is a practice SBS test prepared in the same structure with the actual SBS test that comprises 5 sections: Math, Science and Technology, Social Sciences, Turkish, and Foreign Language. It is a multiple-choice test and there are 15 items in the foreign language section. The second instrument is the Student Background Survey with 40 items related with some student and classroom level factors. In this study, items related with the student level factors were selected. They can be classified as parental education level (recent diploma level, number of books at home), family income level (family possessions like a house or a car, possessions of the students like a cell phone, internet access, individual room, and study desk), out-of-school activities involved and their frequencies (watching TV, playing computer games, online chats, spending time with friends, housework, etc.), and attitude to foreign language (enjoying, finding it easy, finding it boring, finding it important to learn, liking the teacher, etc.).

\section{Data Analysis}

Together with descriptive statistics (frequency, mean, median, and standard deviation), data was analyzed by using two-way ANOVA to identify whether the foreign language test results differ according to region and gender. Scheffe test was employed in order to identify the reasons of the differences amongst regions and gender. In order to carry out region-based two-way variation analysis to test the normality of distribution, Kurtosis and Skewness coefficients, mean and median values were examined. Multiple Linear Regression was conducted to identify the variables that associated with foreign language achievement of 7 th grade students. When interpreting the regression analysis, standardized Beta ( $\beta$ ) coefficients and t-test results for their significance (at the levels of .01 and .05) were used.

\section{Results}

Findings are reported in two sections: (a) Foreign language achievement in relation with region and gender, (b) Predicting foreign language achievement. Findings regarding foreign language achievement in relation with region and gender show that in the foreign language test, the most successful region is Marmara with the score of 54 and the least successful region are South East Anatolia with the score of 33. The average score of all regions is 48. The results of ANOVA that was employed to see if there is a significant difference between the foreign language test scores and regions and gender show that foreign language achievement shows significant differences according to region $\left(F_{(6,4560)}=24.712, p=.000\right.$, $\left.\eta^{2}=.031\right)$ to the advantage of Marmara Region. This result is parallel with many national and international studies' results showing that students at the rural areas are academically less successful than their peers in urban areas. Achievement also shows significant difference according to gender $\left(F_{(1,4560)}=11.208, p=.002, \eta^{2}=.002\right)$. That girls outperform boys is a result that was found in many other 
national research studies. Gender is also a predicting variable for foreign language achievement at country level. However, region and gender do not have common effect $\left(F_{(6,4560)}=.221, p=.970, \eta^{2}=.000\right)$ on the foreign language achievement. The results of Scheffe test show that there is a significant difference between the results of foreign language test between Aegean Region and South East Anatolian Region. While gender is identified as a significant factor in foreign language achievement $\left(F_{(1,4560)}=11.208, p=.002, \eta^{2}=.002\right)$, gender and region together do not have a common effect on foreign language achievement $\left(F(6,4560)=221, p=.970, \eta^{2}=.000\right)$.

The descriptive findings show that students in general have a positive attitude towards foreign language lessons $(\bar{X}=25.62, s d=4.96, n=4338)$. Parental education level was assessed with the number of books at home and the recent school that parents graduated from. According to this, $44 \%$ of the parents $(\mathrm{N}=2012)$ are from low, 33\% $(\mathrm{N}=1511)$ are from medium, and $14 \%(\mathrm{~N}=626)$ are from high level of education. The family income level was assessed with the possession of a house and/or a car, access to internet at home, and possession of a cellphone by the student. According to this, $3 \%(\mathrm{~N}=90)$ of families are from low, $12 \%(\mathrm{~N}=359)$ are from medium, and $86 \%(\mathrm{~N}=2662)$ are from high level of income. However, 1471 students did not answer the questions to identify family income level. Out-of-school activities are offered as watching TV, playing computer games, hanging out with friends, housework, doing sports, chatting with friends online, calling and text messaging with friends, spending time with family, and reading books. The frequency of student participation to out-of-school activities show that $10 \%(\mathrm{~N}=449)$ of students do not participate in any out-of-school activities, $52 \%(\mathrm{~N}=2387)$ engage in an activity less than an hour, $24 \%(\mathrm{~N}=1106)$ engage in an activity for 1 to 2 hours, $2 \%(\mathrm{~N}=105)$ engage in an activity between 3 to 5 hours, and only $0.1 \%(N=5)$ engage in an activity for more than 5 hours.

The regression analysis shows that variables of region, gender, parental education level, family's income level, attitude and out-of-school activities altogether predict $16 \%$ of students' foreign language achievement at country level $(\mathrm{F}=77.791, \mathrm{R}=.398, \mathrm{p}=.000)$. All variables but one are meaningful predictors in the positive direction at $p<.01$ level; only family income level is a positive and meaningful predictor at $p<.05$ level. Parental education level is an important predicting variable both at Turkey level and every region except for East and South East Anatolia. Family income level is a predicting variable in Turkey but not in individual regions. Attitude towards learning a foreign language is a predicting variable of learning a foreign language in Turkey; however, it is a meaningful predictor only in the regions of Marmara, Black Sea, and Central Anatolia. Out-of-school activities are a predicting variable for foreign language achievement in the negative direction in Turkey, whereas it is a meaningful predicting variable in the negative direction only in the regions of Mediterranean, Black Sea, and Central Anatolia.

\section{Discussion, Conclusion \& Implementation}

According to the results of this study, Marmara Region had the highest average score in the foreign language test South East Anatolia Region had the lowest average score. This result shows that regional differences in terms of highly populated urban areas have an effect on foreign language achievement. The related literature shows that in Turkey the level of inadequate and imbalanced schooling, lack of teachers, and inadequate physical infrastructure in the rural areas increase inequity in education; thus impacting academic achievement in a negative way (Ferreira \& Gignoux, 2010; Gök, 2004; İçer, 1997). The results show that girls' foreign language test results are higher than boys' both regionally and countrywide, which is a consistent result with other similar studies carried out in Turkey (Aydın, 2006; Ferreira \& Gignoux, 2010; Özkal \& Çetingöz, 2006). The parental education level is an important predicting variable both in the regions, except for East Anatolian and South East Anatolian Regions, and nationwide. The report named Inequality in Education: Turkey Report shows that family's background is an important factor causing inequality in education regarding academic achievement in the subject areas of Turkish language, Mathematics, and Science (Ferreira \& Gignoux, 2010). This study has a similar result with that report in the subject area of foreign language. Parental education background is an important and consistent predicting variable for academic achievement as found in various national and international research studies (Acar \& Öğretmen, 2012; Berberoğlu, Çelebi, Özdemir, Uysal \& Yayan, 
2003; Davis-Kean, 2005; Jimerson, Egeland \& Theo, 1999; Luster, Rhoades \& Haas, 1989; Ramirez, 2006). This study also shows that students' positive attitude to learning a foreign language is a predicting variable for academic achievement nationwide; however for the region-wide, it is a significant predictor only in Marmara, Black Sea, and Central Anatolia Regions. Students' feelings, attitudes and beliefs towards a specific course have positive and strong effect on solving the problems that a student faces related with that course, the time that a student allocates for learning activities and the amount of effort s/he puts, and eventually learning outcomes related with this course (Van den Broeck, et al., 2005). In regards with out-of-school activities, this is a negative predicting variable nationwide for foreign language achievement; however, regionally it is a negative predicting variable only in the Regions of Meditarrenean, Black Sea, and Central Anatolia. In a study that TIMSS 1999 data was examined (Ceylan \& Berberoğlu, 2007), there is a small negative correlation between out-of-school activities and students' science achievement.

In this study, the results show that variables of gender, parental education level, family income level, attitude, and out-of-school activities altogether predict students' foreign language achievement at the country level. The model established with these variables offer meaningful results for each individual region except for East and South East Regions. In these two regions, all of these variables give insignificant results at $p<.05$ level. This can be explained by the limitation of the sample size in these two regions. Although the sample size is parallel with TUIK's regional population rates, the small sample size in these two regions may have influenced the results of the study. Therefore, it is recommended that a similar study with a larger sample size in these two regions can be performed to make in depth interpretations regarding these predicting variables. 


\section{Öğrencilerin Yabancı Dil Başarısını Açıklayan Etmenler}

\section{Sinem VATANARTIRAN ${ }^{*}$, Gülay DALGIç ${ }^{\mathrm{a}}$, Şirin KARADENiZ ${ }^{\mathrm{a}}$}

${ }^{\text {a} B a h c ̧ e s ̧ e h i r ~ U ̈ n i v e r s i t e s i, ~ E g ̆ i t i m ~ B i l i m l e r i ~ F a k u ̈ l t e s i, ~ I ̇ s t a n b u l / T u ̈ r k i y e ~}$

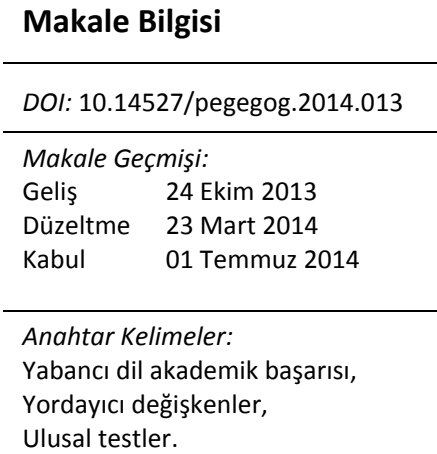

\begin{abstract}
Öz
Bu araştırmada, Türkiye'deki 7. sınıf öğrencilerinin yabancı dil alanındaki başarılarını yordamaya yardımcı olacak öğrenci seviyesindeki bazı faktörlerin ortaya konması hedeflenmektedir. Öğrencilerin yabancı dil testindeki başarıları ile ilişkili olabilecek değişkenleri yordamaya yönelik Çoklu Doğrusal Regresyon Analizi yapılmıştır. Analiz sonuçlarına göre, bölge, cinsiyet, aile eğitim durumu, aile mali durumu, tutum ve okul dışı etkinlikler değişkenlerinin Türkiye genelinde ( $F=77.791, R=.398, p=.000)$ yabancı dil başarısını \% 16 oranında açıkladığı saptanmıştır. Tüm değişkenler yabancı dil başarısında pozitif yönde ve en az p<.05 düzeyinde anlamlı yordayıcı olarak bulunmuştur. Bu değişkenlerden oluşturulan model tüm bölgelerde anlamlı sonuçlar verirken, sadece Doğu ve Güney Doğu Anadolu Bölgelerinde bu değişkenler $p<.05$ düzeyinde anlamsız sonuç vermektedir.
\end{abstract}

\section{Giriş}

Akademik başarıya etki eden öğrenci özelliklerinin belirlenmesine katkı sağlamış pek çok araştırma yapılmıştır. Bu tür çalışmalarda, eğitimde etkililik üzerine geliştirilmiş kavramsal çerçevelerin kullanılması büyük oranda yol göstericidir. Örneğin, Carroll'un “Okul Öğrenme Modeli” (Carroll, 1963), Edmonds'ın “Beş Faktör Modeli” (Edmonds, 1979), Creemers'ın (1994) "Kapsamlı Etkili Eğitim Modeli”, Scheerens ve Bosker'ın (1997) "14 Etkililik Faktörü Modeli" akademik başarıya etki eden pek çok faktörü irdeleyerek bir araya getirmektedir. Bu faktörler, ülke, okul, sınıf ve öğrenci düzeylerine göre sınıflandırılıp incelenebilirler. Ülke düzeyinde öğrenci akademik başarısına etki edebilecek faktörleri inceleyen araştırmalarda, etkililik üzerine ulusal politikaların belirlenmesi ve uygulanması, ulusal değerlendirme sistemleri, öğrenci çıktılarına dayalı bütçelemeler, eğitim müfredatlarına yönelik ulusal yönergeler ve haftalık ders saatleri gibi faktörler ve bu faktörlerle ilgili tutarlılık, süreklilik ve kontrol mekanizmaları (Buchmann ve Hannum, 2001; Creemers, 1994; Ramirez, 2006) öne çıkmaktadır.

Okul düzeyinde akademik başarıya etki eden faktörler ise, okul tarafından sınıf içi öğretime yönelik oluşturulan kurallar ve uygulamalar, değerlendirme sistemleri, okul kültürü, haftalık ders çizelgeleri, olumlu öğrenme ortamı, okul müfredatı, okuldaki kaynaklar, öğretmenler tarafından onaylanmış ve paylaşılan misyon gibi faktörler olarak belirlenmiştir (Cotton, 1995; Hanushek, 1997; Levine ve Lezotte, 1990; Purkey ve Smith, 1983; Sammons, Hillman ve Mortimore, 1995; Scheerens, 1992, 2004). Temel ısınma/soğutma/aydınlanma sistemleri, mekanların metre kare olarak yeterliği gibi fiziki koşulları yeterli okulların yanı sıra, okuldaki kitap sayısı, öğretim materyallerinin sayısı, teknolojik alt yapı gibi koşullar da okul seviyesinde başarıyı etkileyen faktörler arasında gösterilmektedir. Akademik başarıyı öne çıkaran, öğrencilerine iddialı hedefler koyan, motivasyonu yüksek, yetkin öğretmenlerle çalışan, güvenli ve disiplinli okul ortamlarını sağlayan okullarda okuyan öğrencilerin akademik başarılarının daha yüksek olduğu görülmektedir. Bu faktörlerle akademik başarı arasındaki ilişkileri inceleyen araştırmalarda, ülkeler arası ve bir ülkedeki bölgeler arası farklılıklar da irdelenmektedir (Bos ve Kuiper, 1999; Ramirez, 2006; Woessmann, 2004; Yang, 2003; Zhao, 2013).

*Yazar: sinem.vatanartiran@es.bahcesehir.edu.tr 
Akademik başarıya etki eden faktörlerle ilgili araştırmalar çoğunlukla sınıf ve öğrenci seviyesine yoğunlaşmıştır. Sınıf seviyesindeki faktörlere bakıldığında, müfredat, öğretmenin öğrenci gruplama yöntemleri, sınıf yönetimi, ev ödevleri, öğretmen beklentileri, öğretim yöntemleri, okul dışı öğrenmeye ayrılan zaman gibi faktörlerle öğrencilerin akademik başarıları arasında ilişkilere yönelik pek çok araştırma yapılmışırı (Bettencourt ve DuBois, 2002; Bos ve Kuiper, 2010; Davis-Kean, 2005; Leung, 2002; Valentine, Cooper, Won ve Han, 2010; Zhao, 2013). Öğrenci merkezli öğretim yöntemlerinin, haftalık çizelgede belli derslere ayrılan zamanın, düzenli ve güvenli sınıf ortamlarının akademik başarıyla anlamlı ilişkisi vardır. Ancak öğrencilerin kendi öğrenme ortamlarını nasıl algıladıkları da önemli bir faktör olarak Bennett ve Ward'ın (1993) ve McDowell'ın (1995) çalışmalarında, öğrencilerin bu algılarının öğrenme süreci ve öğrenme çıktılarında etkisi olarak öne çıkmaktadır. Hatta öğrenme çıktılarının açıklanmasında, öğrencilerin öğrenme ortamına yönelik kendi algılarının, öğretmenlerin algılarından daha önemli olduğu da belirtilmektedir.

Öğrenci düzeyindeki faktörlerde ise özellikle öğrencinin cinsiyetinin yanı sıra (Acar ve Öğretmen, 2012; Atar, 2010; Bos ve Kuiper, 2010; Ceylan ve Berberoğlu, 2007; Davis-Kean, 2005; Ferreira ve Gignoux, 2010; Uzun ve Öğretmen, 2010; Webster ve Fisher, 2000; Yücel, Karadağ ve Turan, 2013) öğrenci özellikleri olarak genel yetenek, zeka, özel yetenek(ler), ön başarı, ve motivasyon gibi özellikler öne çıkarken, aile ile ilgili özelliklerde ailenin sosyo ekonomik statüsü önemli bir faktör olarak göze çarpmaktadır. Sosyo ekonomik düzeye yönelik en önemli çalışmalardan birisi, Coleman, Campbell, Hobson, McPartland, Mood, Weinfall ve York'un 1966 yııında yayımladıkları çalışmadır. Coleman vd.'nin çalışmasının yanı sıra, ıverson ve Walberg'in çalışması da (1982), akademik başarının sosyo psikolojik çevre ile güçlü ilişkisi olduğunu ve ailenin sosyo ekonomik seviyesinden ziyade ev ortamındaki entelektüel stimülasyonun daha etkili olduğunu ortaya koymaktadır. Birçok başka çalışma da aile özellikleri ile başarı arasındaki ilişkiye değinmekte ve ailenin sosyo ekonomik düzeyi ve etnik geçmişinin başarıda önemli göstergeler olduğunu ortaya koymaktadır (Aydın, Sarıer ve Uysal, 2012; Bradley, Caldwell ve Rock, 1988; Coleman, 1966; Davis-Kean, 2005; Dekkers, Bosker, ve Driessen, 2000; Jencks, vd., 1972; Van den Broeck, Opdenakker ve Van Damme, 2005). Sosyo ekonomik düzeyi belirlerken, öğrencinin kendisinden ailesinin maddi durumuna yönelik gerçekçi bilgiler alınamayacağı için, araştırmalarda genellikle anne ve babanın eğitim seviyeleri, evdeki kitap sayısı veya ailenin sahip olduğu mülkler gibi bilgilerden faydalanılmaktadır (Van den Broeck, Opdenakker ve Van Damme, 2005; Zhao, 2013). Öğrencilerin duygularının, tutumlarının ve inançlarının karşılaştıkları problemlere karşı çözüm yollarını belirlemede, belli bir alandaki öğrenme etkinliklerine yönelik ortaya konulan çabaya ayrılan zaman ve yoğunluğun da önemli rol oynadığı belirlenmiştir (Davis-Kean, 2005; Schoenfeld, 1988; Van den Broeck, Opdenakker ve Van Damme, 2005).

Öğrencilerin belirli alanlardaki akademik becerilerini ve akademik becerilerin öğrenci, sınıf, okul ve ülke seviyesindeki bazı faktörlerle ilişkilerini ölçme amaçlı uluslararası boyutta uygulanan bazı projeler vardır. Örneğin, ilk olarak 1994-1995 yıllarında gerçekleştirilen Uluslararası Matematik ve Fen Bilgisi Çalışması (TIMSS) en geniş ve en kapsamlı karşılaştırmalı uluslararası eğitim çalışmalarından birisidir. Eğitim politikasını belirleyenlerin, öğretim programlarını hazırlayan uzmanların ve araştırmacıların kendi eğitim sistemlerinin işleyişini daha iyi anlayabilmeleri açısından bir temel sağlamak amacıyla düzenlenen TIMSS, beşinci sınıf düzeyindeki öğrencilerin Matematik ve Fen Bilgisi başarılarını karşılaştırmaktadır. Anketleri, video-kaset kayıtlarını ve öğretim programı materyallerinin analizlerini kullanarak, TIMSS, katıııcı ülkelerde Matematik ve Fen Bilgisi öğrenimi için var olan koşul ve çevreleri de araştırmaktadır. Eğitim sistemleri, öğretim programları, öğretmen ve okulların karakteristik özellikleri ve ders anlatımı hakkında da bilgiler toplanmaktadır (TIMSS, 2003). Bir diğer büyük proje de, Uluslararası Eğitim Başarılarını Belirleme Kuruluşu (IEA)'nın Uluslararası Okuma Becerilerinde Gelişim Projesi (PIRLS)'dir. Türkiye de dahil olmak üzere 35 ülkenin katıldığı bu projede ilköğretim 4. sınıf (9 yaş grubu) öğrencilerinin okuma becerileri, okuma alışkanlıkları, öğrencilere okuma becerisini kazandırmak için öğretmenlerin uyguladıkları öğretim yöntemleri, öğretim materyallerinin yeterli olup olmadığı, öğrencilerin okuma becerilerini kazanmalarında ailelerinin katkıları gibi konular uluslararası standart test ve anketlerle belirlenmekte ve projeye katılan ülkelerin verileri ile karşılaştırılarak benzerlik ve farklııklar ortaya çıkarılmaktadır (PIRLS, 2003). Öğrencilerin, matematik, fen ve okuma becerileri alanlarındaki bilgi 
ve becerilerinin değerlendirildiği uluslararası en büyük eğitim araştırması Uluslararası Öğrenci Değerlendirme Programı - PISA (The Program for International Student Assessment)'dır. Üç yılda bir yapılan bu araştırmayla, OECD üyesi ülkeler ve diğer katılımcı ülkelerdeki (dünya ekonomisinin yaklaşık olarak \%90’ı) 15 yaş grubu öğrencilerin modern toplumda yerlerini alabilmeleri için gereken temel bilgi ve becerilere ne ölçüde sahip oldukları değerlendirilmektedir (PISA, 2010). Uluslararası yapılan bu değerlendirme sonuçları, ülkeler tarafından ilgiyle takip edilmekte ve ulusal eğitim politikalarının iyileştirilmesinde bu sonuçlardan faydalanılmaktadır.

Türkiye, son 15 yıldır TIMSS ve PISA gibi uluslararası değerlendirme projelerine dahil olmaktadır. Bu projelerin Türkiye raporları, kamuoyunda ilgiyle karşılanmakta ve araştırmacılar tarafından detaylı analizler yapılarak bilimsel yayın olarak paylaşılmaktadır. Bu çalışmalara benzer bir pilot çalışma, 2008 yılında özel bir eğitim araştırma merkezi tarafından yürütülmüş ve araştırmanın değerlendirmesi iki ayrı rapor şeklinde sunulmuştur (Doğan, 2008; Kelly ve Chen, 2008). Türkiye'de ulusal akademik karnelerin oluşturulabilmesi ve eğitimde ulusal hesap verebilirlik kavramının yerleşebilmesi amacıyla, yurtdışındaki benzerleri gibi, ülke çapında 164 şubesi olan bir dershanenin 7 bölgede bulunan 64 şubesine devam eden öğrencilerle yapılan bu pilot çalışmada, ülke çapında 7. ve 8. sınıflara devam eden ve ortaöğretime geçiş amaçlı yapılan merkezi Seviye Belirleme Sınavı'na hazırlanan öğrencilerin akademik başarıları ile alan yazında değinilen öğrenci ve sınıf seviyesindeki bazı faktörler arasındaki ilişkiler incelenmiştir. Geçerliği ve güvenirliği yapılmış, gerçek Seviye Belirleme Sınavı'na denk olarak hazırlanan ve 5 bölümden (Matematik, Fen ve Teknoloji, Türkçe, Sosyal Bilgiler ve Yabancı Dil) oluşan bir deneme sınavının sonuçları ile, öğrenciler tarafından doldurulan, 4 bölüm ve toplam 40 sorudan oluşan Öğrenci Bilgi Anketinden elde edilen veriler incelenmiştir. Anketin hazırlanma sürecinde TIMSS, PISA, PIRLS, ve NAEP gibi bazı ulusal ve uluslararası akademik değerlendirme sınavlarında kullanılan öğrenci, öğretmen, okul, eğitim sistemi boyutları ile ilgili özelliklerin akademik başarı ile ilişkilerini belirlemek amacıyla var olan anketlerden faydalanılmış ve alan yazından destek alınmıştır. Ankette öğrenci ve sınıf seviyesinde faktörlerle ilgili bilgi toplanılması hedeflenmiş ve "Ev ortamı", "Eğitimle ilgili deneyimler", "Okul dışı etkinlikler", "Tutumlar ve inançlar" ile ilgili sorular sorulmuştur.

$\mathrm{Bu}$ araştırma, yukarıda bahsedilen özel bir eğitim araştırma kurumu tarafından yürütülen pilot çalışmada elde edilen verilerle yürütülmüştür. Bu araştırmayla, Türkiye'deki 7. sınıf öğrencilerinin yabancı dil alanındaki başarılarını yordamaya yardımcı olacak öğrenci seviyesindeki bazı faktörlerin ortaya konması hedeflenmektedir. Yapılan alan yazında, öğrencilerin özellikle matematik ve fen alanlarında akademik becerilerine etki eden faktörlere yoğunlaşıldığı görülmüş, ancak özellikle yabancı dil becerilerini yordamaya yarayacak faktörlerle ilgili bir araştırmaya rastlanmamıştır. Bu sebeple bu araştırmanın, alan yazına büyük oranda katkı sağlayacağı düşünülmektedir. Araştırmada pilot çalışmada kullanılan verilerden sadece Yabancı Dil akademik sonuçları ve Öğrenci Bilgi Anketi'nin öğrenci seviyesindeki bölümleri (Cinsiyet, Ev Ortamı, Okul Dışında Geçirilen Vakit ve Tutum) kullanılmıştır. Araştırmada şu sorulara yanıt aranmıştır:

- 7. sınıf öğrencilerinin yabancı dil alanında bölgelere ve cinsiyete göre akademik başarı durumları nedir?

- Öğrencilerin yabancı dil başarısı Türkiye'deki bölgelere ve cinsiyete göre farklılık göstermekte midir?

- Bölge, cinsiyet, öğrencinin yabancı dil öğrenimine karşı tutumu, okul dışı etkinlikler, ailenin eğitim ve mali durumu değişkenleri Türkiye çapında ve bölgeler özelinde öğrencilerin yabancı dil başarılarını anlamlı bir şekilde yordamakta mıdır? 


\section{Yöntem}

\section{Örneklem}

Çalışmanın evrenini Türkiye'de 7. sınıfa devam eden öğrenciler oluşturmaktadır. Araştırmanın örneklemini, uygun örnekleme yöntemi kullanılarak belirlenen Türkiye'de Seviye Belirleme Sınavı'na hazırlanmak üzere ülke çapında 164 şubesi olan bir dershanenin 7 bölgede bulunan 64 şubesine devam eden 4.582 öğrenci oluşturmaktadır. Araştırmaya katılan öğrencilerin 2308'i kız (\%50.4), 2266'sı ise erkektir (\%49.5). Bu öğrencilerin 651'i (\%14.2) Akdeniz, 104'ü (\%2.3) Doğu Anadolu, 928'i (\%20.3) Ege, 38'i (\%0.8) Güneydoğu Anadolu, 930’u İç Anadolu (\%20.3), 577’si (\%12.6) Karadeniz, 1354'ü ise (\%29.6) Marmara Bölgesinden araştırmaya katılmışlardır. Araştırma örnekleminin bölgelere göre dağılımı ve TUiK'in (2008) adrese dayalı nüfus sayımının bölgelere göre dağılımı arasında fark olup olmadığı Ki-Kare testi ile kontrol edilmiştir. Sonuca göre Türkiye'de örneklemin dağılımı ile TUik'in belirlediği nüfusun bölgelere göre yüzde olarak dağılımı arasında anlamlı bir fark olmadığı belirlenmiştir $\left(x^{\wedge} 2=35.00\right.$, $\mathrm{p}=.243$ ). Bu nedenle uygun örnekleme yöntemi kullanılarak ulaşılan çalışma grubunun evreni temsil ettiği söylenebilir.

\section{Veri Toplama Araçları}

$\mathrm{Bu}$ araştırmada iki veri toplama aracı kullanılmıştır. Öğrencilerin akademik başarılarını değerlendirmek için Milli Eğitim Bakanlığı tarafından düzenlenen Seviye Belirleme Sınavı (SBS) yapısında ve 5 alandan oluşan bir deneme sınavının Yabancı Dil Testi ve bu sınavla birlikte öğrenciler tarafından doldurulan Öğrenci Bilgi Anketi kullanılmıştır.

\section{Yabancl dil testi}

İlk veri toplama aracı, geçerliği ve güvenirliği yapılmış, gerçek Seviye Belirleme Sınavı yapısında ve 5 bölümden (Matematik, Fen ve Teknoloji, Türkçe, Sosyal Bilgiler ve Yabancı Dil) oluşan bir deneme sınavıdır. Araştırmanın kapsamına aldığımız Yabancı Dil Testi, 15 çoktan seçmeli sorudan oluşmaktadır. Oluşturulan testin kapsam geçerliği sürecinde MEB öğretim programı dikkate alınarak bir kazanım listesi hazırlanmıştır. Kazanımlar arasında seçim yapılırken çok özel veya çok genel kazanımlardan kaçınılmış ve her bir kazanımın belirli ve açık sorularla ölçülmesine özen gösterilmiştir. Test son halini almadan önce 5 alan uzmanından değerlendirme alınmıştır. Tüm değerlendirenlere testin ana amacı hakkında bilgi verilmiş ve değerlendirmelerin dayandırılması istenen kriterler de testle birlikte bir form halinde sunulmuştur. Uzmanların değerlendirmeleri ışığında testte gerekli düzeltmeler yapılmış ve kapsam geçerliği sağlanmıştır.

Deneme sınavı, gerçek SBS süresi verilerek uygulanmıştır ve uygulama sonucunda testin psikometrik özellikleri incelenerek güvenirlik katsayısı (Cronbach Alpha) .74 olarak bulunmuştur. Yapılan madde analizi sonucuna göre Yabancı Dil testinin madde güçlük değerlerinin .38 ile .55 arasında değişiklik gösterdiği ve ortalamasının .46 olduğu bulunmuştur. Buna göre testteki soruların orta düzeyde zor olduğu söylenebilir. Madde ayırt edicilik gücü ise .15 ile .42 arasında pozitif olarak değişiklik gösterirken, ortalama .30 olarak belirlenmiştir. Testin betimsel istatistik sonuçlarını sunan Tablo 1'e göre başarı puanlarının ortalaması 7.23 ve ortancası 7.00, çarpıklık katsayısı .276 ve basıklık katsayısı .524 'tür. Çarpıklık ve basıklık katsayılarının birden küçük olması, ortalama ve ortanca değerlerinin birbirine yakın olması nedeniyle testten alınan puanların normal dağılım gösterdiği söylenebilir. Bu bulgulara göre madde güçlük ve madde ayırt edicilik değerlerinin kabul edilebilir düzeyde olduğu belirlenmiştir.

Tablo 2'de ise Yabancı Dil testindeki soruların ortalama, standart sapma, toplam puan ile olan korelasyonu ve soru silindiğinde Cronbach alfadaki değişimi gösteren güvenilirlik analiz sonuçları özetlenmektedir. Buna göre maddelerin ortalama değerleri .23 ila .46 arasında değişmektedir. Düzeltilmiş madde toplam korelasyonları .15 ila .42 arasında değişmektedir. Başarı testinin Cronbach alfa değeri toplam için .74 iken, maddeler silindiği noktada artmadığı tablodan görünmektedir. Bu bulgular ışığında, testin kabul edilebilir düzeyde güvenilir olduğu söylenebilir. 
Tablo 1.

Yabancı Dil Testi için Betimsel İstatistikler.

\begin{tabular}{lr}
\hline Betimsel İstatistikler & Yabancı Dil Testi \\
\hline Soru sayısı & 15.00 \\
Uygulanan kişi sayısı & 4546.00 \\
Ortalama & 7.23 \\
Ortanca & 7.00 \\
Standart sapma & 3.31 \\
Çarpıklık & .276 \\
Basıklık & -.524 \\
Cronbach Alpha & 0.74 \\
Ortalama madde güçlüğü & .46 \\
Ortalama madde ayırt ediciliği & .30 \\
\hline
\end{tabular}

Tablo 2.

Yabancı Dil Testi Soru Özellikleri.

\begin{tabular}{ccccc}
\hline Sorular & $\overline{\mathbf{X}}$ & sd & $\begin{array}{c}\text { Düzeltilmiş Madde } \\
\text { Toplam r }\end{array}$ & $\begin{array}{c}\text { Soru Silindiğinde } \\
\text { Alfa }\end{array}$ \\
\hline Soru 1 & .46 & .498 & 0.25 & .73 \\
Soru 2 & .60 & .490 & 0.25 & .73 \\
Soru 3 & .60 & .489 & 0.25 & .73 \\
Soru 4 & .45 & .498 & 0.20 & .73 \\
Soru 5 & .56 & .496 & 0.36 & .72 \\
Soru 6 & .57 & .495 & 0.40 & .72 \\
Soru 7 & .55 & .498 & 0.42 & .72 \\
Soru 8 & .57 & .495 & 0.39 & .72 \\
Soru 9 & .54 & .499 & 0.15 & .74 \\
Soru 10 & .58 & .494 & 0.30 & .73 \\
Soru 11 & .57 & .496 & 0.31 & .73 \\
Soru 12 & .52 & .500 & 0.19 & .72 \\
Soru 13 & .46 & .498 & 0.34 & .72 \\
Soru 14 & .54 & .499 & 0.32 & .73 \\
Soru 15 & .60 & .491 & 0.30 & \\
\hline
\end{tabular}

\section{Öğrenci bilgi anketi}

Araştırmada kullanılan ikinci veri toplama aracı, 4 bölüm ve toplam 40 sorudan oluşan Öğrenci Bilgi Anketidir. Anketin hazırlanma sürecinde TIMSS, PISA, PIRLS, ve NAEP gibi bazı ulusal ve uluslararası akademik değerlendirme sınavlarında kullanılan öğrenci, öğretmen, okul, eğitim sistemi boyutları ile ilgili özelliklerin akademik başarı ile ilişkilerini belirlemek amacıyla geliştirilmiş anketlerden faydalanılmış ve alan yazından destek alınmıştır. Öğrenci ve sınıf seviyesindeki faktörlerle ilgili 4 bölüm ve 40 sorudan oluşan ankette, "Ev ortamı", "Eğitimle ilgili deneyimler", "Okul dışı etkinlikler", "Tutumlar ve inançlar" ile ilgili sorular sorulmuş ve anket maddeleri 2, 3 ve 4 noktalı Likert tipinde hazırlanmıştır. Bu araştırma, sadece öğrenci seviyesindeki faktörleri incelediği için, anketin ilgili bölümleri ve soruları Tablo 3'te sunulduğu şekilde araştırma kapsamına alınmıştır. 
Tablo 3.

Öğrenci Bilgi Anketi Soruları.

\begin{tabular}{|c|c|}
\hline Bölüm & Sorular \\
\hline \multirow[t]{2}{*}{ Ailenin Eğitim Durumu } & Anne ve babanın eğitim durumu \\
\hline & Evde bulunan kitap sayısı \\
\hline \multirow[t]{2}{*}{ Ailenin Mali Durumu } & Ailenin sahip olduğu mülkler (araba, ev, işyeri) \\
\hline & $\begin{array}{l}\text { Öğrencinin sahip olduğu imkanlar (cep telefonu, internet erişimi, bireysel } \\
\text { oda, çalışma masası) }\end{array}$ \\
\hline Okul Dışı Etkinlikler & $\begin{array}{l}\text { Okuldan sonra yapılan etkinlikler ve sıklıkları (televizyon izleme, bilgisayar } \\
\text { oyunu oynama, arkadaşlarla vakit geçirme, ev işi yapmak, vb) }\end{array}$ \\
\hline Tutum & $\begin{array}{l}\text { Yabancı dil dersine karşı tutum (keyif almak, kolay bulmak, sıkıcı bulmak, } \\
\text { önemli bulmak, öğrenemediğini hissetmek, öğretmenini sevmek) }\end{array}$ \\
\hline
\end{tabular}

\section{Verilerin Analizi}

Betimsel analizlerde frekans, ortalama, ortanca ve standart sapma kullanılmıştır. Bölge ve cinsiyete göre yabancı dil puanlarının farklılaşıp farklılaşmadığını belirlemek üzere iki yönlü ANOVA kullanılmıştır. Bölgeler arasındaki farklılıkların nelerden kaynaklandığını belirlemek için de Scheffee testi yapılmıştır. Iki yönlü varyans analizini gerçekleştirmek için bölgelere göre basıklık ve çarpıklık katsayıları ile ortalama ve ortanca değerleri dikkate alınmıştır. 7. sınıf öğrencilerinin Seviye Belirleme Sınavı'nın Yabancı Dil testindeki başarıları ile ilişkili olabilecek değişkenleri yordamaya yönelik Çoklu Doğrusal Regresyon Analizi yapılmıştır. Regresyon analizinin yorumlanmasında standartlaştırılmış Beta $(\beta)$ katsayıları ve bunların anlamlılığına ilişkin t-testi sonuçları dikkate alınmıştır. Verilerin analizinde .01 ve 05 anlamlılık düzeyleri esas alınmıştır.

\section{Bulgular}

\section{Bölgelere ve Cinsiyete Göre Yabancı Dil Başarısı}

Tablo 4 incelendiğinde, yabancı dil başarısının tüm bölgeler dikkate alındığında 48 olduğu, bölgeler arasında ise en yüksek başarı puanının 54 ile Marmara Bölgesinde, en düşük puanın ise 33 ile Güneydoğu Anadolu Bölgesinde olduğu görülmektedir.

Tablo 4.

Bölgelere Göre Yabancı Dil Başarısı.

\begin{tabular}{|c|c|c|c|c|c|c|c|c|c|}
\hline Bölge & Cinsiyet & $\overline{\mathrm{X}}$ & sd & $\mathbf{N}$ & Bölge & Cinsiyet & $\overline{\mathrm{X}}$ & sd & $\mathbf{N}$ \\
\hline \multirow{3}{*}{ Akdeniz } & Erkek & 44.05 & 21.36 & 316 & \multirow{3}{*}{ İç Anadolu } & Erkek & 42.96 & 22.31 & 491 \\
\hline & $\mathrm{K} ı \mathrm{z}$ & 47.07 & 20.70 & 333 & & $\mathrm{~K} \mathrm{Iz}$ & 46.54 & 19.58 & 438 \\
\hline & Toplam & 45.60 & 21.06 & 649 & & Toplam & 44.65 & 21.13 & 929 \\
\hline \multirow{3}{*}{$\begin{array}{c}\text { Doğu } \\
\text { Anadolu }\end{array}$} & Erkek & 40.41 & 20.25 & 49 & \multirow{3}{*}{ Karadeniz } & Erkek & 42.73 & 21.49 & 278 \\
\hline & $\mathrm{K} ı \mathrm{Z}$ & 47.78 & 18.03 & 54 & & $\mathrm{~K} ı \mathrm{Z}$ & 46.80 & 20.33 & 299 \\
\hline & Toplam & 44.27 & 19.38 & 103 & & Toplam & 44.84 & 20.98 & 577 \\
\hline \multirow{3}{*}{ Ege } & Erkek & 44.75 & 23.79 & 446 & \multirow{3}{*}{ Marmara } & Erkek & 51.72 & 23.59 & 708 \\
\hline & $\mathrm{K} ı \mathrm{z}$ & 49.47 & 21.67 & 480 & & $\mathrm{~K} ı \mathrm{Z}$ & 55.37 & 22.71 & 644 \\
\hline & Toplam & 47.20 & 22.82 & 926 & & Toplam & 53.46 & 23.24 & 1352 \\
\hline \multirow{3}{*}{$\begin{array}{c}\text { Güneydoğu } \\
\text { Anadolu }\end{array}$} & Erkek & 31.33 & 19.84 & 20 & \multirow{3}{*}{ Total } & Erkek & 45.96 & 23.06 & 2308 \\
\hline & $\mathrm{K} ı \mathrm{Z}$ & 35.19 & 19.78 & 18 & & $\mathrm{~K} ı \mathrm{Z}$ & 49.72 & 21.50 & 2266 \\
\hline & Toplam & 33.16 & 19.64 & 38 & & Toplam & 47.83 & 22.38 & 4574 \\
\hline
\end{tabular}


Tablo 5'te yabancı dil başarısının bölgeler ve cinsiyete göre farklılık gösterip göstermediğini belirlemek üzere yapılan ANOVA sonucu sunulmaktadır. Buna göre yabancı dil başarısının bölgelere göre farklılık gösterdiği $\left(F(6,4560)=24.712, p=.000, \eta^{\wedge} 2=.031\right)$ ve bu farkın Marmara Bölgesi lehine olduğu söylenebilir. Ayrıca Scheffe sonucuna göre Ege Bölgesi ve Güneydoğu Anadolu Bölgesinin yabancı dil başarıları arasında da anlamlı fark olduğu belirlenmiştir. Yabancı dil başarısının cinsiyete göre anlamlı farklılık gösterdiği $\left(F(1,4560)=11.208, p=.002, \eta^{\wedge} 2=.002\right)$ ancak cinsiyet ve bölgenin yabancı dil başarısı üzerinde ortak etkileri olmadığı belirlenmiştir $\left(F(6,4560)=.221, p=.970, \eta^{\wedge} 2=.000\right)$. Son olarak etki büyüklükleri dikkate alındığında ise yabancı dil başarısı üzerinde bölgenin güçlü bir etkisi olduğu ancak cinsiyetin düşük düzeyde bir etkisi olduğu görülmektedir.

Tablo 5.

Bölgelere ve Cinsiyete Göre Yabancı Dil Başarısı ANOVA Sonuçları

\begin{tabular}{lrrrrrrl}
\hline Kaynak & $\begin{array}{c}\text { Kareler } \\
\text { Toplamı }\end{array}$ & sd & $\begin{array}{r}\text { Ortalama } \\
\text { Kareler }\end{array}$ & $\mathbf{F}$ & $\mathbf{p}$ & $\begin{array}{c}\text { Eta } \\
\text { Kare }\end{array}$ & Anlamlı Fark \\
\hline Model & 88518.499 & 13 & 6809.115 & 14.104 & .000 & .039 & Marmara \\
Bölge & 71581.349 & 6 & 11930.225 & 24.712 & .000 & .031 Tüm Bölgeler; \\
Cinsiyet & 5410.920 & 1 & 5410.920 & 11.208 & .001 & .002 Güneydoğu \\
Bölge*Cinsiyet & 639.010 & 6 & 106.502 & .221 & .970 & $.000 \begin{array}{l}\text { Anadolu } \\
\text { Ege }\end{array}$ \\
Hata & 2201473.602 & 4560 & 482.779 & & & & \\
Toplam & 12751955.556 & 4574 & & & & & \\
\hline
\end{tabular}

\section{Yabancı Dil Başarısının Yordanması}

Öğrencilerin yabancı dil başarılarının Türkiye ve bölge bazında cinsiyet, tutum, okul dışı etkinlikler ve ailenin eğitim durumu değişkenleri tarafından yordanmasına geçmeden önce bazı betimsel sonuçları incelenmiştir. Buna göre öğrencilerin yabancı dil dersine karşı tutumlarının olumlu olduğu belirlenmiştir $(\bar{X}=25.62, \mathrm{sd}=4.96, \mathrm{n}=4338)$.

Çalışmaya katılan öğrencilerin ailelerinin eğitim durumu ailenin evde sahip olduğu kitap sayısı ve anne-babanın en son mezun oldukları okul düzeyleri bilgileriyle değerlendirilmiştir. Buna göre ailelerin eğitim durumu incelendiğinde \%44'ünün ( $n=2012$ ) düşük (okuma yazma bilmeyen, okuma yazma bilen ya da ilkokul mezunu), \%33'ünün ( $n=1511$ ) orta (ortaokul ya da lise dengi okul mezunu) ve \%14'ünün ( $n=626$ ) yüksek (yüksekokul, üniversite, yüksek lisans ya da doktora mezunu) eğitim düzeyine sahip olduğu görülmektedir. Ailelerin mali durumu ise sahip olunan ev ve araba sayısı ile öğrencinin sahip olduğu internet erişimi, cep telefonu gibi kaynaklarla değerlendirilmiştir. Çalışmaya dahil olan ailelerin mali durumu değerlendirildiğinde \%3'ünün ( $n=90)$ düşük, \%12'sinin ( $n=359)$ orta ve \%86'sının ( $n=2662)$ yüksek gelir düzeyine sahip olduğu görülmektedir. Ancak ailenin mali durumunu belirlemek için sorular sorulara toplam 1471 öğrenci cevap vermemiştir.

Öğrencilerin belirli okul dışı etkinliklere katılım sıklıklarına bakıldığında okul dışında herhangi bir etkinlikte bulunmayanların oranı \%10 ( $n=449)$, herhangi bir etkinlikte 1 saatten az meşgul olanların oranı $\% 52(n=2387), 1-2$ saat arası meşgul olanların oranı \%24 ( $n=1106), 3-5$ saat arası meşgul olanların oranı $\% 2(n=105), 5$ saatten fazla meşgul olanların oranı ise \%0.1'dir $(n=5)$.

Öğrencilerin okul dışı etkinliklere ayırdıkları sürelere bakıldığında:

$\% 46$ 'sının günde 1-2 saat televizyon izlediği;

\%38'inin hiç bilgisayar oyunu oynamadığı ve \%31'inin 1 saatten az bilgisayar oynadığı;

\%33'ünün arkadaşlarıyla 1 saatten az vakit geçirdiği;

\%50'sinin hiç ev işi yapmadığı ancak \%38'inin 1 saatten az ev işi yaptığı;

\%36'sının günde 1 saatten az spor yaptığı ve \%33'ünün ise hiç spor yapmadığı; 
\%44'ünün bilgisayar ortamında hiç sohbet etmediği ancak \%33'ünün 1 saatten az bilgisayar ortamında sohbet ettiği;

\%60'ının telefonda hiç konuşup mesaj çekmediği ancak \%30'unun 1 saatten az telefonda konuşup mesaj çektiği;

$\% 35$ 'inin ailesiyle günde 1-2 saat vakit geçirdiği;

\%46'sının günde 1 saatten az kitap okuduğu belirlenmiştir.

Yabancı dil başarısının yordanmasına ilişkin yapılan çoklu doğrusal regresyon analizi sonuçları ise Tablo 6'da verilmiştir. Bu değişkenler (bölge, cinsiyet, aile eğitim durumu, aile mali durumu, tutum ve okul dışı etkinlikler) Türkiye genelinde $(F=77.791, R=.398, p=.000)$ yabancı dil başarısını $\% 16$ oranında açıklamaktadır. Aile maddi durumu dışındaki tüm değişkenler yabancı dil başarısında pozitif yönde ve $p<.01$ düzeyinde anlamlı yordayıııken, aile maddi durumu pozitif yönde $p<.05$ düzeyinde anlamlı yordayıcı olarak görülmektedir.

Bölgeler bazında ise Marmara Bölgesinde, belirlenen yordayııı değişkenler birlikte yabancı dil başarısıyla anlamlı bir ilişki göstermektedir ( $F=31.437, R=.416, p=.00)$. Bu değişkenler, yabancı dil başarısındaki varyansın \%17'sini açıklamaktadır. Sadece aile eğitim durumu $(\beta=.363, p=.01)$ ve tutum $(\beta=.173, p<.01)$ boyutları öğrencinin yabancı dil başarısını pozitif yönde ve anlamlı düzeyde yordarken cinsiyet $(\beta=.037, p>.05)$, aile mali durumu $(\beta=-.001, p>05)$ ve okul dışı etkinlikler $(\beta=-.011, p>.05)$ ise yabancı dil başarısında anlamlı yordayıcı olmadıkları görülmektedir.

Ege Bölgesindeki öğrencilerin yabancı dil başarısı belirlenen yordayıcılar ile anlamlı bir ilişki göstermektedir $(F=21.042, \quad R=449, \quad p=.00)$. Bu değişkenler yabancı dil başarısının \%20'sini açıklayabilmektedir. Oluşturulan modelde cinsiyet $(\beta=.094, p<.05)$ ve aile eğitim durumu $(\beta=.403$, $p<.01)$ öğrencinin yabancı dil başarısını pozitif yönde ve anlamlı düzeyde yordamaktadır. Ancak Ege Bölgesinde ailenin mali durumu $(\beta=-.073, p>.05)$, tutum $(\beta=-.002, p>.05)$ ve okul dışı etkinliklerin $(\beta=-$ $.023, p>.05$ ) yabancı dil başarısının anlamlı yordayıcısı olmadığı belirlenmiştir.

Akdeniz Bölgesinde ise belirlenen yordayıcı değişkenlerin birlikte yabancı dil başarıııla anlamlı bir ilişki gösterdiği $(F=8.742, R=.338, p=.00)$ ve varyansın \%11.5'ini açıkladığı bulunmuştur. Modelde aile eğitim durumu $(\beta=.248, p<.01)$ ve okul dışı etkinlikler $(\beta=-.114, p<.01)$ öğrencinin yabancı dil başarısını pozitif yönde ve anlamlı düzeyde yordarken, cinsiyet $(\beta=.086, p>.05)$, aile mali durumu $(\beta=-1.771, p>.05)$ ve tutum $(\beta=-.028, p>.05)$ yabancı dil başarısının anlamlı yordayıcıları değildir.

Yordayıcı değişkenler birlikte Karadeniz Bölgesindeki öğrencilerin yabancı dil başarısıyla anlamlı bir ilişki göstermekte ( $F=18.031, R=.457, p=.00)$ ve başarının \% 21'ini açıklamaktadır. Aile eğitim durumu ( $\beta=.367, p=.00)$, tutum $(\beta=.144, p<.01)$ ve okul dışı etkinlikler $(\beta=-.129, p<.01)$ öğrencinin yabancı dil başarısını pozitif yönde ve anlamlı düzeyde yordarken; cinsiyet $(\beta=.056, p>.05)$ ve aile mali durumu $(\beta=-$ .053, p> .05) yabancı dil başarısının anlamlı yordayıcısı olmadığı görülmektedir.

iç Anadolu Bölgesinde, belirlenen yordayıcı değişkenler öğrencilerin yabancı dil başarısı ile anlamlı bir ilişki göstermekte $(F=19.825, R=.397, p=.00)$ ve varyansın \% 16'sını açıklamaktadır. Cinsiyet $(\beta=.081$, $p<.05)$, aile eğitim durumu $(\beta=.326, p=.00)$, tutum $(\beta=.165, p=.00)$ ve okul dışı etkinlikler ( $\beta=-.129$, $p<.01)$ öğrencinin yabancı dil başarısını pozitif yönde ve anlamlı düzeyde yordarken aile mali durumunun $(\beta=-.053, p>.05)$ anlamlı bir yordayıcı olmadığı belirlenmiştir.

Belirlenen yordayıcı değişkenlerin birlikte yabancı dil başarısını Doğu $(F=1.441, R=.332, R 2=.111$, $\mathrm{p}>.05$ ) ve Güneydoğu Anadolu ( $F=1.579, \mathrm{R}=705, \mathrm{R} 2=.497, \mathrm{p}>.05$ ) bölgelerinde anlamlı bir şekilde yordamadığı görülmüştür. Çoklu doğrusal regresyon analizi sonucunda her iki bölgede de belirlenen değişkenler $p<.05$ düzeyinde yabancı dil başarııının anlamlı yordayıcıları olarak görülmemektedir. Analiz sonuçları, bu iki coğrafi bölgede yabancı dil başarısını yordayan bu değişkenlerin dışında farklı değişkenlerin de incelenmesi gerektiğini göstermektedir. 


\section{Sonuç, Tartışma ve Öneriler}

Araştırma sonucuna göre, yabancı dilde en yüksek başarı puanı Marmara Bölgesinde, en düşük puan ise Güney Doğu Anadolu Bölgesinde görülmüştür. Bu sonuç özellikle kentleşmenin yoğun olduğu ve olmadığı bölgeler arasından yabancı dil başarısı açısından ülkemiz adına önemli farklılıklar olduğunun bir göstergesidir. İlgili alan yazın incelendiğinde Türkiye'de kırsal alanlardaki yetersiz ve dengesiz okullaşma düzeyinin, öğretmen yetersizliğinin ve okullardaki fiziki alt yapı yetersizliğinin, eğitimde fırsat eşitsizliğini artırması nedeniyle akademik başarı üzerine olumsuz etkiler olduğu görülmektedir (Ferreira ve Gignoux, 2010; Gök, 2004; İ̧̧er, 1997). Özellikle Doğu ve Güney Doğu Anadolu bölgelerinde okul kayıt oranları, Türkiye ortalamasının çok altındadır (Aydın, vd., 2012). TIMSS 2011 Ulusal Ön Değerlendirme Raporuna göre, nüfusu 100.000 ve üzeri yerleşim yerlerindeki öğrencilerin matematik ortalama başarı puanlarının, 15.000 nüfusun altında olan yerleşim yerlerindeki öğrencilerin ortalama başarı puanlarından daha yüksek olması sonucu da, kırsal bölgelerin akademik başarı açısından dezavantajı durumda olduklarıı göstermektedir (Yücel, vd., 2013). Kırsal alanlarda yaşayan öğrencilerin, daha büyük yerleşim yerlerinde yaşayan akranlarına göre daha düşük akademik başarı göstermelerine yönelik uluslararası alan yazın paralel sonuçlar göstermektedir (Meng, 2012; Qian ve Smyth, 2008; Webster ve Fisher, 2000; Wu, 2010; Zhao, 2013). Büyük yerleşim yerlerinde yaşayan öğrencilerin kırsal alandakilere göre daha yüksek akademik başarı göstermeleri, ailenin daha yüksek eğitim seviyesine ve aile gelirine sahip olmasına, okul kalitesinin daha iyi olmasına ve devlet tarafından eğitime ayrılan bütçenin bu bölgelerde daha çok harcanmasına bağlanmaktadır (Zhao, 2013).

Tablo 6.

Yabancı Dil Başarısının Yordanmasına iliş̧kin Regresyon Analizi Sonuçları.

\begin{tabular}{|c|c|c|c|c|c|c|}
\hline & Değişken & $B$ & Sh & B & $t$ & $p$ \\
\hline \multirow[t]{6}{*}{ Marmara } & Sabit & 12.266 & 12.224 & & 1.003 & .316 \\
\hline & Cinsiyet & 1.693 & 1.513 & .037 & 1.119 & .263 \\
\hline & Aile Eğitim Durumu & 2.033 & .202 & .363 & 10.068 & .000 \\
\hline & Aile Mali Durumu & -.008 & .495 & -.001 & -.015 & .988 \\
\hline & Tutum & .782 & .150 & .173 & 5.195 & .000 \\
\hline & Okul Dışı Etkinlikler & -.068 & .210 & -.011 & -.322 & .748 \\
\hline \multirow[t]{6}{*}{ Akdeniz } & Sabit & 65.881 & 17.562 & & 3.751 & .000 \\
\hline & Cinsiyet & 3.516 & 2.087 & .086 & 1.685 & .093 \\
\hline & Aile Eğitim Durumu & 1.169 & .272 & .248 & 4.291 & .000 \\
\hline & Aile Mali Durumu & -1.268 & .716 & -.104 & -1.771 & .077 \\
\hline & Tutum & -.112 & .208 & -.028 & -.538 & .591 \\
\hline & Okul Dışı Etkinlikler & -.596 & .275 & -.114 & -2.163 & .031 \\
\hline \multirow[t]{6}{*}{ İç Anadolu } & Sabit & 18.895 & 12.487 & & 1.513 & .131 \\
\hline & Cinsiyet & 3.424 & 1.711 & .081 & 2.001 & .046 \\
\hline & Aile Eğitim Durumu & 1.723 & .226 & .326 & 7.615 & .000 \\
\hline & Aile Mali Durumu & -.037 & .523 & -.003 & -.070 & .944 \\
\hline & Tutum & .689 & .169 & .165 & 4.066 & .000 \\
\hline & Okul Dışı Etkinlikler & -.794 & .251 & -.129 & -3.159 & .002 \\
\hline Güney Doğu & Sabit & -72.130 & 59.933 & & -1.204 & .263 \\
\hline \multirow[t]{5}{*}{ Anadolu } & Cinsiyet & 6.215 & 9.807 & .178 & .634 & .544 \\
\hline & Aile Eğitim Durumu & .929 & 1.578 & .176 & .589 & .572 \\
\hline & Aile Mali Durumu & .417 & 2.133 & .054 & .196 & .850 \\
\hline & Tutum & 2.451 & 1.133 & .590 & 2.164 & .062 \\
\hline & Okul Dışı Etkinlikler & 1.001 & 1.510 & .177 & .662 & .526 \\
\hline
\end{tabular}


Tablo 6 Devamı.

Yabancı Dil Başarısının Yordanmasına Iliş̧kin Regresyon Analizi Sonuçları.

\begin{tabular}{|c|c|c|c|c|c|c|}
\hline & Değişken & B & Sh & B & $t$ & $p$ \\
\hline \multirow[t]{6}{*}{ Ege } & Sabit & 39.869 & 15.610 & & 2.554 & .011 \\
\hline & Cinsiyet & 4.203 & 1.970 & .094 & 2.133 & .033 \\
\hline & Aile Eğitim Durumu & 2.042 & .249 & .403 & 8.206 & .000 \\
\hline & Aile Mali Durumu & -.976 & .654 & -.073 & -1.492 & .137 \\
\hline & Tutum & -.010 & .203 & -.002 & -.051 & .960 \\
\hline & Okul Dışı Etkinlikler & -.140 & .268 & -.023 & -.524 & .600 \\
\hline \multirow[t]{6}{*}{ Karadeniz } & Sabit & 30.926 & 14.743 & & 2.098 & .037 \\
\hline & Cinsiyet & 2.317 & 1.991 & .056 & 1.164 & .245 \\
\hline & Aile Eğitim Durumu & 1.920 & .277 & .367 & 6.923 & .000 \\
\hline & Aile Mali Durumu & -.615 & .605 & -.053 & -1.018 & .310 \\
\hline & Tutum & .679 & .235 & .144 & 2.888 & .004 \\
\hline & Okul Dışı Etkinlikler & -.719 & .270 & -.129 & -2.662 & .008 \\
\hline \multirow[t]{6}{*}{ Doğu Anadolu } & Sabit & 7.513 & 46.954 & & .160 & .873 \\
\hline & Cinsiyet & 9.225 & 5.070 & .231 & 1.820 & .074 \\
\hline & Aile Eğitim Durumu & 1.380 & .746 & .270 & 1.849 & .069 \\
\hline & Aile Mali Durumu & 1.178 & 1.739 & .102 & .677 & .501 \\
\hline & Tutum & .053 & .477 & .014 & .110 & .913 \\
\hline & Okul Dışı Etkinlikler & -.695 & .862 & -.113 & -.806 & .423 \\
\hline \multirow[t]{7}{*}{ Türkiye Geneli } & Sabit & 26.024 & 6.297 & & 4.133 & .000 \\
\hline & Bölge & 1.151 & .192 & .111 & 6.006 & .000 \\
\hline & Cinsiyet & 3.137 & .808 & .072 & 3.882 & .000 \\
\hline & Aile Eğitim Durumu & 1.761 & .107 & .333 & 16.534 & .000 \\
\hline & Aile Mali Durumu & -.590 & .255 & -.047 & -2.316 & $.021 *$ \\
\hline & Tutum & .450 & .082 & .102 & 5.484 & .000 \\
\hline & Okul Dışı Etkinlikler & -.359 & .112 & -.060 & -3.206 & .001 \\
\hline
\end{tabular}

${ }^{*} \mathrm{p}<, 05$

Araştırma sonucunda kız öğrencilerin yabancı dil başarı puanlarının hem Türkiye genelinde hem de bölgeler özelinde erkek öğrencilerden daha yüksek olması, Türkiye'de yapılan diğer çalışmaların bulgularıyla paralellik göstermektedir (Aydın, 2006; Ferreira ve Gignoux, 2010; Özkal ve Çetingöz, 2006). DPT ve Dünya Bankası "Eğitimde Fırsat Eşitliği: Türkiye Örneği" çalışma raporunda, özellikle Türkçe branşında, kız öğrencilerden yana cinsiyetten kaynaklanan fark en yüksek düzeyde belirlenmiştir. Bu durum, okullu kız çocuklarının ortalama yeteneğinin okullu erkek çocuklarına göre daha yüksek olabileceği şeklinde yorumlanmışır, çünkü Türkiye'de şu ana kadar okula giden kız çocuklarının başarı düzeyinin okula giden erkek çocuklardan daha düşük olduğuna ilişkin herhangi bir bulgu yoktur (Ferreira ve Gignoux, 2010). Cinsiyetler arasındaki bu fark kız öğrencilerin yabancı dil öğrenmeye yönelik tutumlarının daha olumlu olması yönünde de açıklanabilmektedir (Kubota, 2003). Bu bulgular da ikinci dil öğrenimi ve cinsiyet ilişkisini öne çıkarmaktadır. Cinsiyet ayrıca, Türkiye genelinde yabancı dil başarısını yordayan bir değişken olarak da görülmektedir. Fakat bölgeler bazında sadece Ege ve iç Anadolu Bölgelerinde yabancı dil başarısını pozitif yönde ve anlamlı düzeyde yordayan bir değişken olarak öne çıkmaktadır.

Ailenin eğitim durumu, hem Türkiye genelinde hem de bölgeler bazında Doğu ve Güney Doğu Anadolu Bölgeleri hariç tüm bölgelerde, önemli bir yordayıcı değişken olarak kendini göstermektedir. Eğitimde Fırsat Eşitsizliği: Türkiye Örneği Raporuna tekrar bakılacak olduğunda, Türkçe, Matematik ve 
Fen Bilgisi branşlarında aile alt yapısı, Türkiye'de eğitimde başarı düzeyi ile ilgili fırsat eşitsizliğinin başat kaynağı olarak öne çıkmaktadır (Ferreira ve Gignoux, 2010). Bu çalışmayla benzer bir sonuç yabancı dil dersi için de görülmektedir. Ailenin eğitim durumunun akademik başarıya olumlu bir etkisinin olması, gerek ulusal gerek uluslararası pek çok çalışmada da sürekli ve tutarlı olarak öne çıkan bir değişkendir (Acar ve Öğretmen, 2012; Berberoğlu, vd., 2003; Davis-Kean, 2005; Jimerson, Egeland ve Theo, 1999; Luster, Rhoades ve Haas, 1989; Ramirez, 2006). Bu nedenle son yıllardaki çalışmalar daha çok ailenin eğitim durumunun akademik başarıya nasıl etki ettiğini açıklamaya yönelik modeller geliştirmek üzerinedir (Linver, Brooks-Gunn ve Kohen 2002; Mistry, Vanderwater, Houston ve McLoyd, 2002; Yeung, Linver ve Brooks-Gunn, 2002).

Ailenin maddi durumu Türkiye genelinde yabancı dil başarısını 05 düzeyinde açıklayan bir yordayıcı olarak görülürken, bölgeler bazında yabancı dil başarısının anlamlı bir yordayıcısı olmadığı belirlenmiştir. Bölgelere göre yabancı dil başarısının ANOVA sonucuna göre bölgenin, yabancı dil başarısı üzerinde güçlü etkisi olduğu görülmüştür. Bölgeler arasında ailelerin maddi durumunu karşılaştırmak için yapılan Ki-Kare sonucu ise yine Türkiye'de bölgeler arasında ailelerin maddi durumu arasında anlamlı farklılık olduğunu göstermiştir $\left(x^{\wedge} 2=74.29, p=.000\right)$. Ancak ailenin maddi durumu her bölge içerisindeki incelemede diğer değişkenler ile birlikte ele alındığında yabancı dil başarısını yordayan bir değişken olmamaktadır. Ailenin maddi durumu, bölgeler arası farklılık gösterdiği için Türkiye genelinde yabancı dil başarısı için yapılan regresyon modelinde anlamlı bir yordayıcı olarak ortaya çıktığı düşünülmektedir.

Bu çalışmada, Türkiye genelinde öğrencinin yabancı dil öğrenmeye karşı olumlu tutumu, başarısında olumlu yönde etki eden bir yordayıcıyken, bölgeler bazında sadece Marmara, Karadeniz ve íç Anadolu bölgelerinde anlamlı bir yordayıcı olduğu görülmektedir. Belirli bir derse karşı öğrencinin duygu, tutum ve inançlarının bu dersle ilgili karşılaştığı problemleri çözme yollarına, öğrenme etkinliklerine ayırdığı zamana ve çabanın yoğunluğuna, ve en sonunda bu dersle ilgili öğrenme çıktılarına güçlü bir etkisi vardır (Van den Broeck, vd., 2005). Belirli bir dersten keyif almak, iyi öğrenme çıktılarını desteklerken o derse karşı duyulan korku veya ilgi azlığı öğrenme çıktılarını olumsuz yönde etkiler. TIMSS 1999 matematik ve fen branşlarında Türkiye verilerinin incelendiği bir çalışmada, öğrencilerin bu derslere karşı tutumları ve sosyo ekonomik düzeylerinin matematik ve fen başarılarını etkileyen en önemli faktörler olarak belirlenmiştir (Berberoğlu, vd., 2003). Ancak, Ceylan ve Berberoğlu'nun (2007) bir diğer çalışmasında ise tutumlarla başarı arasında kuramsal olarak beklenen olumlu ilişkinin tersine bir sonuç ortaya çıkmış ve öğrencilerin fen bilgisi dersine yönelik tutumlarıyla başarıları arasında negatif bir ilişki ortaya çıkmıştır. Tutum ve başarı arasında negatif ilişki belirleyen çalışmalar, öğrencilerin belirli bir branşta olumlu tutum geliştirmiş olmalarına rağmen, o branştaki temel kavram ve becerileri öğrenememiş olmaları şeklinde açıklanabilmektedir (Ceylan ve Berberoğlu, 2007).

Okul dışı etkinlikler Türkiye genelinde yabancı dil başarısını negatif yönde yordayan bir değişken iken, bölgeler bazında sadece Akdeniz, Karadeniz ve iç Anadolu Bölgelerinde negatif yönde anlamlı bir yordayıcı olarak görülmektedir. TIMSS 1999 verilerinin incelendiği bir çalışmada da (Ceylan ve Berberoğlu, 2007), okul dışı etkinlikler ile öğrencilerin fen başarıları arasında küçük bir negatif ilişki tespit edilmiştir. Buna göre öğrencilerin televizyon izleme, bilgisayar oyunu oynama, arkadaşlarla vakit geçirme veya ev işi yapma gibi etkinliklere ayırdıkları zaman arttıkça, yabancı dil başarılarında düşme görülmektedir. Bu durum, ülkemizdeki yabancı dil müfredatının yoğun ve zor olması nedeniyle öğrencilerin okul dışı etkinliklere çok katılmalarının müfredata ve ders ödevlerine yeteri kadar zaman ayırmıyor olmaları ile açıklanabilir; çünkü TIMSS başarı ölçümlerinde üst sıralarda bulunan Singapur, Japonya ve Hong Kong gibi ülkelerde öğrencilerin okul dışı etkinlik olarak spora ayırdıkları zamanın, TIMSS'e katılan diğer ülkelerden daha fazla olduğu görülmektedir (Leung, 2002, Akt. Ceylan ve Berberoğlu, 2007).

Bu çalışmada, cinsiyet, ailenin eğitim durumu, ailenin maddi durumu, tutum ve okul dışı etkinlikler değişkenleri birlikte Türkiye genelinde yabancı dil başarısını yordayan değişkenler olarak belirlenmiştir. Bu değişkenlerden oluşturulan model tüm bölgelerde anlamlı sonuçlar verirken, sadece Doğu ve Güney Doğu Bölgelerinde bu değişkenler $p<.05$ düzeyinde anlamsız sonuç vermektedir. Bu durum, araştırmanın aslında örneklem kısıtının etkili olabileceğini düşündürmektedir. Çünkü her ne kadar örneklem sayısı 
bölgelere göre TÜik oranları ile benzeşik olsa da, Doğu ve Güney Doğu Anadolu Bölgelerinin örneklem sayısının küçük olması, araştırma sonuçlarını etkilemiş olabilmektedir. Bu nedenle, bu yordayıcı değişkenlerle ilgili bu bölgelere yönelik kesin yorumlarda bulunabilmek için daha geniş bir popülâsyonla benzeri bir çalışma yürütülmelidir.

\section{Kaynakça}

Aydın, A., Sarıer, Y., \& Uysal, Ş. (2012). Sosyo ekonomik ve sosyo kültürel değişkenler açısından PISA Matematik sonuçlarının karşılaştırılması. Eğitim ve Bilim, 37(164), 20-30.

Aydın, S. (2006). İinci dil olarak İngilizce öğrenimindeki başarı düzeyinin bazı değişkenlere göre incelenmesi. Atatürk Üniversitesi Sosyal Bilimler Enstitüsü Dergisi, 8(2), 273-283.

Bennett, R. E. \& Ward, W. C. (1993). Construction versus choice in cognitive measurement. Hillsdale, NJ: Erlbaum.

Berberoğlu, G., Çelebi, Ö., Özdemir, E., \& Yayan, B. (2003). 3. Uluslararası Matematik ve Fen Çalışması'nda Türk öğrencilerinin başarı düzeylerini etkileyen etmenler. Eğitim Bilimleri ve Uygulama, 2(3), 3-14.

Boekaerts, M. (1999). Self-regulated learning: Where are we today? International Journal of Educational Research, 31, 445-456.

Bos, K. \& Kuiper, W. (2010). Modelling TIMMS data in a Europe and comparative perspective: Exploring influencing factors on achievements in mathematics in grade 8.Educational Research and Evaluation: An International Journal on Theory and Practice, 5(2), 157-179.

Bradley, R. H., Caldwell, B. M., \& Rock, S. L. (1988). Home environment and school performance: A tenyear follow-up and examination of three models of environmental action. Child Development, 59, 852-867.

Buchmann, C. \& Hannum, E. (2001). Education and stratification in developing countries: A review of theories and research. Annual Review of Sociology, 27, 77-102.

Carroll, J. B. (1963). A model of school learning. Teachers College Record, 64, 723-733.

Carroll, J. B. (1989). The Carroll model. A 25-year retrospective and prospective view. Educational Researcher, 18, 26-31.

Ceylan, E. \& Berberoğlu, G. (2007). Öğrencilerin fen başarısını açıklayan etmenler: Bir modelleme çalışması. Eğitim ve Bilim, 32(144), 36-48.

Creemers B. P. M. (1994). The effective classroom. London: Cassell.

Coleman, J., Campbell, E., Hobson, C., McPartland, J., Mood, A., Weinfall, F., \& York, R. (1966). Equality of educational opportunity. Washington, DC: Department of Health, Education and Welfare.

Cotton, K. (1995). Effective schooling practices: A research synthesis. 1995 Update. School Improvement Research Series. Northwest Regional Educational Laboratory.

Davis-Kean, P. E. (2005). The influence of parent education and family income on child achievement: The indirect role of parental expectations and home environment. Journal of Family Psychology, 19(2), 294-304.

Dekkers, H. P. J. M., Bosker, J. R., \& Driessen, G. W. J. M. (2000).Complex inequalities of educational opportunities. A large-scale longitudinal study on the relation between gender, social lass, ethnicity, and school success. Educational Research and Evaluation, 6, 59-82.

Doğan, E. (2008). SBS II deneme sinavi psikometrik özellikleri. American Institute for Research (AIR), Washington DC.

Edmonds, R. R. (1979). Effective schools for the urban poor. Educational Leadership, 37(1), 15-27. 
Sinem VATANARTIRAN, Gülay DALGIÇ ve Şirin KARADENiZ - Pegem Eğitim ve Öğretim Dergisi, 4(3), 2014, 01-18

Ferreira, F. H. G. \& Gignoux, J. (2010). Eğitimde fırsat eşitsizliği: Türkiye örneği. T.C. Cumhuriyeti DPT ve Dünya Bankası Refah ve Sosyal Politika Analitik Çalışma Programı. Çalışma Raporu 4. Ankara.

Gök, F. (2004). Eğitim hakkı: Türkiye gerçeği. XIII. Ulusal Eğitim Bilimleri Kurultayı, 6-9 Temmuz 2004, İnönü Üniversitesi Eğitim Fakültesi, Malatya.

Hanushek, E.A. (1997). Assessing the effects of school resources on student performance: an update.Educational Evaluation and Policy Analysis, 19, 141-164.

İçer, M. M. (1997).Türkiye'de eğitim sisteminin genel amaçlari ve temel eğitim ilkelerinin değerlendirilmesi. Unpublished master's thesis,, İnönü Üniversitesi Sosyal Bilimler Enstitüsü, Malatya.

Iverson, B K. \& Walberg, H. J. (1982). Home environment and school learning: A quantitative synthesis. Journal of Experimental Education, 50, 144-151.

Jencks, C., Smith, M. S., Acklan, H., Bane, M. J., Cohen, D., Grintlis, H., Heynes, B., \& Michelson, S. (1972). Inequality. New York. Basic Books.

Jimerson, S., Egeland, B., \& Teo, A. (1999). A longitudinal study of achievement trajectories factors associated with change. Journal of Educational Psychology, 91, 116-126.

Kelly, D.L. \&Chen, D.S. (2008). Öğrenci performansı ve öğrenci arka plan değişkenleri raporu. American Institute for Research (AIR), Washington DC.

Kubota, R. (2003). New approaches to gender, class, and race in second language writing.Journal of Second Language Writing, 12, $31-47$.

Leung, F. K. (2002). Behind the high achievement of East Asian students. Educational Research and Evaluation, 8, 87-108.

Levine, D.K. \& Lezotte, L.W. (1990).Unusually effective schools: A review and analysis of research and practice. Madison, Wise: Nat. Centre for Effective Schools Research and Development.

Linver, M. R., Brooks-Gunn, J., \& Kohen, D. E. (2002). Family processes as pathways from income to young children's development. Developmental Psychology, 38, 719-734.

Luster, T., Rhoades, K., \& Haas, B. (1989). The relation between parental values and parenting behavior: A test of the Kohn Hypothesis. Journal of Marriage and the Family, 51, 139-147.

Meng, X. (2012). Impact of economic reform on labor market outcomes in China. Journal of Economics Perspective, 26(4), 75-102.

McDowell, L. (1995). The impact of innovative assessment on student learning. Innovations in Education and Training International, 32, 302-313.

Mistry, R. S., Vandewater, E. A., Houston, A. C., \& McLoyd, V. C. (2002). Economic well-being and children's social adjustment: The role of family process in an ethnically diverse low income sample. Child Development, 73, 935-951.

Özkal, N. \& Çetingöz, D. (2006). Akademik başarı, cinsiyet, tutum ve öğrenme stratejilerinin kullanımı. Kuram ve Uygulamada Eğitim Yönetimi, 46, 259-275.

PIRLS, (2003). PIRLS 2001 Uluslararası okuma becerilerinde gelişim projesi ulusal rapor. MEB Eğitimi Araştırma ve Geliştirme Dairesi Başkanlığı, Ankara.

PISA, (2010). PISA 2009 Ulusal Ön Raporu. MEB Eğitimi Araştırma ve Geliştirme Dairesi Başkanlığı, Ankara, 2010.

Purkey, S.C. \& Smith, M.S. (1983). Effective schools: a review. The Elementary School Journal, 83(4), 427452.

Qian, X. \& Smyth, R. (2008). Measuring regional inequality of education in China: Widening cost-inland gap or widening rural-urban gap? Journal of International Development, 20(2), 132-144.

Ramirez, M. J. (2006). Understanding the low mathematics achievement of Chilean students: A crossnational analysis using TIMSS data. International Journal of Educational Research, 45, 102-116. 
Sammons, P., Hillman, J., \& Mortimore, P. (1995).Key characteristics of effective schools: A review of school effectiveness research. London: OFSTED.

Scheerens, J. \& Bosker, R.J. (1997). The Foundations of educational effectiveness. Oxford: Elsevier Science Ltd.

Scheerens, J. \& Creemers, B. P. M. (1989).Conceptualizing school effectiveness. International Journal of Educational Research, 13, 691-706.

Schoenfeld, A. (1988). When good teaching leads to bad results. The disasters of well-taught mathematics courses. Educational Psychologist, 23, 145-166.

Stringfield, S. C. \& Slavin, R. E. (1992).A hierarchical longitudinal model for elementary school effects. In B. P. M. Creemers \& G. J. Reezigt (Eds), Evaluation of educational effectiveness (pp. 35-69). Groningen, The Netherlands: ICO.

TIMMS, (2003). TIMMS 1999 3.Uluslararası Matematik ve Fen Bilgisi Çalışması Ulusal Rapor. MEB Eğitimi Araştırma ve Geliştirme Dairesi Başkanlığı, Ankara.

Uzun, B. \& Öğretmen, T. (2010). Fen başarısı ile ilgili bazı değişkenlerin TIMSS-R Türkiye örnekleminde cinsiyete gore ölçme değişmezliğinin değerlendirilmesi. Eğitim ve Bilim, 35(155), 26-35.

Valentine, J. C., Cooper, H., Bettencourt, B. A. \& DuBois, D. L. (2002). Out-of-school activities and academic achievement: The mediating role of self-beliefs. Educational Psychologist, 37(4), 245-256.

Van den Broeck, A., Opdenakker, M.C., \& Van Damme, J. (2005). The effects of student characteristics on mathematics achievement in Flemish TIMSS 1999 data. Educational Research and Evaluation: An International Journal of Theory and Practice,11(2), 107-121.

Webster, B. J. \& Fisher, D. L. (2000). Accounting for variation in science and mathematics achievement: A multilevel analysis of Australian data TIMSS. School Effectiveness and School Improvement, 11(3), 339-360.

Woesmann, L. (2004). How equal are educational opportunities? Family background and student achievement in Europe and the United States. Discussion paper, No. 1284. IZA: Bonn

Won, S. J. \& Han, S. (2010). Out-of-school activities and achievement among middle school students in the U.S. and South Korea. .Journal of Advanced Academics, 21(4), 628-661.

Wu, X. (2010). Economic transition, school expansion and educational inequality in China, 19902000.Research in Social Stratification and Mobility, 28(1), 91-108.

Yang, Y. (2003). Dimensions of socio-economic status and their relationship to mathematics and science achievement at individual and collective levels. Scandinavian Journal of Educational Research, 47(1), 21-41

Yeung, W. J., Linver, M. R., \& Brooks-Gunn, J. (2002). How money matters for young children's development: Parental investment and family processes. Child Development, 73, 1861-1879.

Yücel, C., Karadağ, E., \& Turan, S. (2013). TIMSS 2011 Ulusal ön değerlendirme raporu. Eskişehir Osmangazi Üniversitesi Eğitim Fakültesi, Eğitimde Politika Analizi Raporlar Serisi I. Eskişehir.

Zhao, G. (2013). Essays on the effects of parental education and private tutoring on children's education outcomes, and the rural-urban student achievement differential in China. Unpublished doctorate dissertation, The Australian National University, Australia. 